\title{
Prevalence of symptoms and quality of life of cancer patients
}

\author{
Prevalência de sintomas e qualidade de vida de pacientes com câncer \\ Prevalencia de síntomas y de calidad de vida en pacientes con cáncer
}

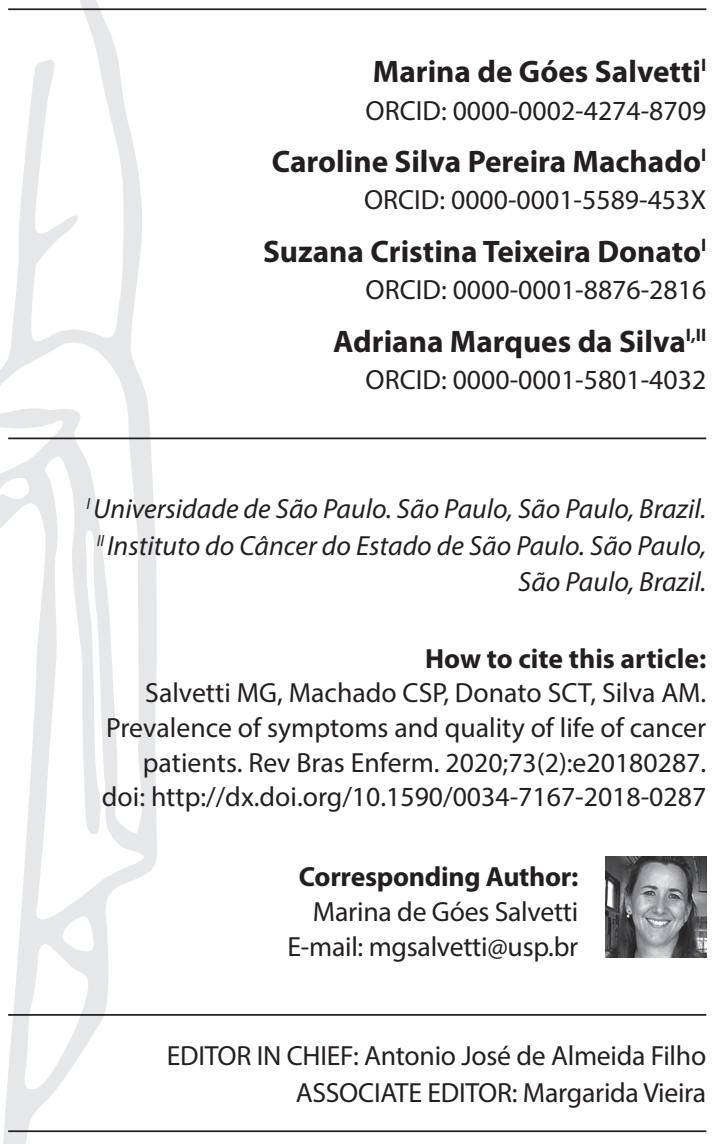

Submission: 05-04-2018 Approval: 11-29-2018

\begin{abstract}
Objectives: to analyze the prevalence of symptoms and their relationship with the quality of life of cancer patients. Methods: this is a cross-sectional study with 107 patients evaluated using a sociodemographic instrument, the hospital anxiety and depression scale (HADS) and the quality of life scale (EORTC-QLQ-C30). Pearson's correlation test was used to evaluate the relationship between symptoms and quality of life. Results: prevalence of female patients $(56.1 \%), 55$ years as the mean age and 10 years of schooling. Fatigue $(76.6 \%)$, insomnia $(47.7 \%)$, pain $(42.1 \%)$, loss of appetite $(37.4 \%)$, anxiety $(31.8 \%)$ and depression (21.5\%) were identified. Anxiety and depression symptoms presented a negative correlation with quality of life and positive correlation with physical symptoms. Conclusions: fatigue, insomnia, pain and loss of appetite were the most common and most intense symptoms. Anxiety and depression symptoms presented a negative correlation with quality of life and positive correlation with physical symptoms.

Descriptors: Oncology Nursing; Neoplasms; Signs and Symptoms; Symptoms Assessment; Quality of Life.
\end{abstract}

\section{RESUMO}

Objetivos: analisar a prevalência de sintomas e sua relação com a qualidade de vida de pacientes com câncer. Métodos: estudo transversal com amostra de 107 pacientes avaliados por meio de formulário sociodemográfico, escala hospitalar de ansiedade e depressão (HADS) e escala de qualidade de vida (EORTC-QLQ-C30). O teste de correlação de Pearson foi utilizado para avaliar a relação entre sintomas e a qualidade de vida. Resultados: predomínio de pacientes do sexo feminino (56,1\%), idade média de 55 anos e escolaridade de 10 anos. Verificou-se fadiga $(76,6 \%)$, insônia $(47,7 \%)$, dor $(42,1 \%)$, perda de apetite $(37,4 \%)$, ansiedade $(31,8 \%)$ e depressão $(21,5 \%)$. Os sintomas de ansiedade e depressão apresentaram correlação negativa com qualidade de vida e correlação positiva com sintomas físicos. Conclusões: fadiga, insônia, dor e perda de apetite foram os sintomas mais frequentes e mais intensos. Sintomas de ansiedade e depressão mostraram correlação negativa com qualidade de vida e positiva com sintomas físicos.

Descritores: Enfermagem Oncológica; Neoplasias; Sinais e Sintomas; Avaliação de Sintomas; Qualidade de Vida.

\section{RESUMEN}

Objetivos: evaluar la prevalencia de síntomas y su relación con la calidad de vida de los pacientes con cáncer. Métodos: estudio transversal con una muestra de 107 pacientes que fueron evaluados por medio de formulario sociodemográfico, de la Escala hospitalaria de ansiedad y depresión (HADS) y de la Escala de calidad de vida (EORTC-QLQ-C30). Se hizo la prueba de correlación de Pearson para evaluar la relación entre los síntomas y la calidad de vida. Resultados: hubo un predominio de pacientes del sexo femenino $(56,1 \%)$, un promedio de edad de 55 años y un nivel de escolaridad de 10 años. Se observaron los siguientes elementos: fatiga $(76,6 \%)$, insomnio $(47,7 \%)$, dolor $(42,1 \%)$, pérdida de apetito $(37,4 \%)$, ansiedad $(31,8 \%$ ) y depresión $(21,5 \%)$. Los síntomas ansiedad y depresión presentaron una correlación negativa con la calidad de vida y una correlación positiva con los síntomas físicos. Conclusiones: la fatiga, el insomnio, el dolor y la pérdida de apetito fueron los síntomas más frecuentes e intensos. Los síntomas ansiedad y depresión se correlacionaron negativamente con la calidad de vida y positivamente con los síntomas físicos.

Descriptores: Enfermería Oncológica; Neoplasias; Signos y Síntomas; Evaluación de Síntomas; Calidad de Vida. 


\section{INTRODUCTION}

The Brazilian Cancer Institute (INCA) estimated 600,000 new cases of cancer in Brazil for the biennium 2018-2019, being those of prostate $(31.7 \%)$, lung (8.7\%) and intestine $(8.1 \%)$ more frequent among men, and breast (29.5\%), intestine $(9.4 \%)$ and cervix (8.1\%) the most frequent among women ${ }^{(1)}$.

Diagnosis, treatment and fear of recurrence cause significant psychological impact in cancer patients, affecting their quality of life $(\mathrm{QOL})^{(2-3)}$. A systematic review identified that the fear of recurrence of cancer has been reported as the greatest cause of concern among patients ${ }^{(4)}$. This study also showed that patients who presented additional symptoms such as fatigue, pain, and body image/appearance issues feared the recurrence of cancer more often $^{(4)}$. These data show the importance of symptom management for coping with the disease; however, such control is still incipient.

Anxiety and depression symptoms can vary according to the stage of the treatment and evolution of the disease, affecting the quality of life, adherence to treatment and self-care. Functioning can also be impaired in anxious/depressed patients, influencing other symptoms and reducing the patient's desire to live ${ }^{(2,5-6)}$.

There are few Brazilian studies on the prevalence of depression and anxiety in cancer patients, with rates ranging from $25 \%$ to $40 \%$, and higher tendencies in patients undergoing chemotherapy ${ }^{(2,7-8)}$.

A study on patients with head and neck cancer undergoing radiation treatment showed dysphoria and depression ranging from $7.3 \%$ to $12.1 \%$ at the beginning of the treatment, and from $9.7 \%$ to $21.9 \%$ in the end, suggesting a great impact of the disease and treatment on emotional aspects ${ }^{(9)}$.

Pain and fatigue are the most prevalent symptoms in cancer patients. Regarding these data, a study that evaluated over 3,000 patients with various types of cancer showed that $67 \%$ reported some kind of pain or need for analgesic drugs at the beginning of the treatment and of these, 33\% were not receiving adequate analgesia $^{(10)}$. In 2016, the World Health Organization (WHO) estimated that about $90 \%$ of cases of pain in patients with cancer could be controlled with simple interventions ${ }^{(11)}$. However, many studies indicate that pain management for these patients is still difficult.

Fatigue is reported by $50 \%$ to $90 \%$ of patients, impairing their quality of life and functioning ${ }^{(12)}$. A study on women with breast cancer, in the state of São Paulo, Brazil, showed that $70.9 \%$ of evaluated patients had symptoms of depression and $71 \%$ presented fatigue ${ }^{(13)}$.

Another study that evaluated women with breast cancer identified clinically relevant fatigue ( $>4$ intensity) in $31.9 \%$ of women, and this symptom was associated with pain and depression $^{(14)}$. In patients with colorectal cancer, fatigue occurred in $26.8 \%$ and predictors were: depression, impaired functioning and sleep disorders ${ }^{(15)}$.

Nausea and vomiting are also common in patients undergoing chemotherapy. A Brazilian study that evaluated women with breast cancer undergoing chemotherapy indicated that $93 \%$ of them presented nausea and $87 \%$ had at least one episode of vomiting during treatment ${ }^{(16)}$. Constipation and diarrhea also occur in patients treated with chemotherapy and radiation therapy ${ }^{(17-18)}$.

An investigation conducted with 75 cancer patients showed that the most prevalent clinical manifestations resulting from treatment were metabolic (89.3\%), such as weight gain or loss; gastrointestinal (74.6\%), such as diarrhea, nausea and vomiting; and psychological (61.7\%), such as insomnia and anxiety. Moreover, pain was reported by $58.6 \%$ of patients, with moderate intensity ( $6.7 \pm 1.83$ mean score), according to the numerical scale of pain ${ }^{(19)}$. In another study conducted in 2016, the prevalence of pain in patients with melanoma was $38.2 \%$, of which $75 \%$ reported some related disability ${ }^{(20)}$.

A large study conducted in the United States in 114 oncology units investigated 810 patients with cancer-related pain. The mean score on the numerical scale of pain was 5.8 , and $25 \%$ of patients reported that they spent more than $50 \%$ of the time feeling constant or intense pain ${ }^{(21)}$. These studies show that the pain has a major impact on the lives of cancer patients, and is often related to impairments to their quality of life.

Insomnia, also common in cancer patients, can be related to stressful events, fatigue and depression, in addition to impairing function ${ }^{(22)}$. This symptom negatively affects the quality of life and can worsen anxiety and depression symptoms ${ }^{(23)}$.

Thus, we can identify the overlap of symptoms that, although common in cancer patients, are not always adequately treated, impairing the quality of life, functioning and self-care, and may even affect the adherence to treatment and its results.

\section{OBJECTIVES}

To analyze the prevalence of symptoms and their relationship with the quality of life of cancer patients undergoing chemotherapy and radiation therapy.

\section{METHODS}

\section{Ethical aspects}

This study followed all ethical precepts of CNS Resolution 466/2012 and Cofen Resolution 311/2007 and was approved by the Research Ethics Committee of the School of Nursing of Universidade de São Paulo. Cancer patients undergoing treatment at the Cancer Institute of the state of São Paulo (Instituto do Câncer do Estado de São Paulo - ICESP), were invited to participate and received information about the goals of the study. Those agreed to participate signed an informed consent form.

\section{Study design, location and period}

This is a transversal descriptive study, developed in the Ou t-patient Chemotherapy and Radiation Therapy units of ICESP from September 2015 to December 2016.

\section{Sample, inclusion and exclusion criteria}

The sample of this study consisted of patients with malignant neoplasm undergoing treatment by chemotherapy or radiotherapy. The inclusion criteria were: confirmed malignant neoplasm diagnosis, being under chemotherapy or radiotherapy treatment; older than 18 years; minimum of four years of schooling, not present language dysfunction and having orientation in 
space and time. Exclusion criteria were: patients who are illiterate or have cognitive disabilities (dementia), and patients with high care demands.

\section{Study protocol}

Study participants were evaluated using a form with sociodemographic and clinical data, Karnofsky Performance Status (KPS) functioning scale ${ }^{(24-26)}$, the Hospital Anxiety and Depression Scale ${ }^{(27-28)}$ and the instrument European Organization for Research and Treatment of Cancer Quality of Life Questionnaire"Core" 30 (EORTC-QLQ-C30)(29).

KPS is a scale that allows the evaluation of the functional capacity and the ability to perform the activities of daily living of cancer patients. The score ranges from 0 to 100, and is established by means of observation by the health professional. Higher scores indicate better functioning capacity ( 0 represents death and 100 represents full physical capacity). This is a widely used functioning scale and its psychometric properties have been tested in several contexts ${ }^{(24-26)}$.

The Hospital Anxiety and Depression Scale is composed of 14 items (with scores from 0 to 3), divided into seven items for evaluation of anxiety (HADS-A), and seven others for the evaluation of depression (HADS-D) ${ }^{(27-28)}$. This scale has been validated for the Portuguese language and presents good validity and reliability levels ${ }^{(27-28)}$. The total score ranges from 0 to 21 in each subscale. According to the literature, the cutting point adopted is a score equal to or greater than 8 as indicative of anxiety (HADS-A), and a score equal to or greater than 9 as indicative of depression (HADS-D) $)^{(27-28)}$.

The instrument EORTC QLQ-C30 assesses the health-related quality of life, and has been validated for Brazilian patients of this population, showing satisfactory psychometric properties ${ }^{(29)}$. This questionnaire consists of 30 questions covering five functioning scales (physical, cognitive, emotional, social and role functioning), and three scales for symptoms (fatigue, pain and nausea and vomiting), a scale for general health/QOL, five items for the evaluation of common symptoms related to cancer treatment (dyspnea, loss of appetite, insomnia, constipation and diarrhea), and an item for the assessment of the financial impact of the disease and treatment ${ }^{(29)}$. The score of each scale ranges from 0 to 100 , considering that higher scores for functioning and QOL indicate better performance, and higher scores for symptoms indicate greater intensity of the symptom ${ }^{(29)}$.

\section{Analysis of results and statistics}

The data were included a database in the Excel software and analyzed in the statistical program Statistical Package for Social Science (SPSS) by means of descriptive and inferential statistics. Pearson's correlation coefficient was used to evaluate the relationship between scores for symptoms and quality of life. Significance was considered for $p>0.05$.

\section{RESULTS}

This study found 162 eligible patients, of whom 23 did not met the study's inclusion criteria, and 32 who refused to participate. Thus, the study sample, by convenience, included 107 patients.
The mean age of participants was 55 years, with 10 years as the mean schooling, and predominance of female patients (56.1\%), who lived with a companion (61.7\%), Catholics (54.2\%), and mean $\mathrm{R} \$ 3,400.00$ mean household income. Table 1 presents the sample's characteristics.

The most common type of cancer among the participants was colorectal $(49.5 \%)$, followed by breast $(24.3 \%)$, prostate (8.4\%) and others (17.8\%). The mean time of diagnosis was 13.1 months ( $S D=16.5), 67.3 \%$ were undergoing chemotherapy, and $32.7 \%$ radiation therapy, with good functioning capacity (mean score in the Karnofsky scale $=89.6$ ).

Table 1 - Distribution of anxiety and depression scores $(N=107)$, São Paulo, São Paulo, Brazil, 2015-2016

\begin{tabular}{llll}
\hline \multicolumn{1}{c}{$\begin{array}{c}\text { Anxiety scale } \\
\text { HADS* }\end{array}$} & \multicolumn{1}{c}{$\begin{array}{c}\text { Depression scale } \\
\text { HADS* }\end{array}$} \\
\hline Yes $($ score $\geq 8)$ & $\mathrm{n}=34(31.8 \%)$ & Yes (score $\geq 9)$ & $\mathrm{n}=23(21.5 \%)$ \\
No $(\mathrm{score} \geq 8)$ & $\mathrm{n}=73(68.2 \%)$ & No $($ score $<9)$ & $\mathrm{n}=84(78.5 \%)$ \\
Mean $\left(\mathrm{SD}^{+}\right)$ & $5.7(3.9)$ & Mean $\left(\mathrm{SD}^{+}\right)$ & $4.7(3.7)$ \\
\hline
\end{tabular}

Note: *HADS - Hospital Anxiety and Depression Scale; ${ }^{+} S D$ - Standard deviation.

The analysis of the prevalence of symptoms, accomplished using the scale of symptoms (QLQ-C30), showed that the most frequent symptoms were fatigue (76.6\%), insomnia $(47.7 \%)$ and pain $(42.1 \%)$, followed by loss of appetite (37.4\%), nausea/ vomiting (33.6\%), constipation (27.1\%), diarrhea (26.2\%) and dyspnea (18.7\%).

Based on the cut-off points adopted for the HADS, depression and anxiety were observed in $31.8 \%$ and $21.5 \%$ of patients, respectively (Table 1 ).

Table 2 shows the mean and standard deviation (SD) of the functioning and symptom scales of EORTC-QLQ-C30, which showed 71.0 (SD = 23.7) as the mean general health score, with greater impairments in physical (mean=71.4; $\mathrm{SD}=25.2$ ) and emotional (mean $=68.1 ; \mathrm{SD}=26.0$ ) functioning. On the scales of symptoms, insomnia was the most common, with 30.5 (SD = 37.2) mean, followed by fatigue $29.2(S D=27.8)$, loss of appetite $25.6(S D=37.6)$ and pain $22.0(S D=32.1)$. The scale on financial difficulties due to the treatment and disease presented $35.5(S D=41.8)$ mean.

Table 3 shows the correspondence between the EORTC-QLQ-C30 and HADS scales, which showed moderate negative correlation between general quality of life and anxiety $(r=-0.477 ; p<0.001)$, and general quality of life and depression $(r=-0.504 ; p<0.001)$, showing that the higher the anxiety and depression scores, the lower the patients' general quality of life.

Negative correlation between physical functioning and depression was also observed $(r=-0.487 ; p<0.001)$, role functioning and depression $(r=-0.523 ; p<0.001)$, and emotional functioning and depression $(r=-0.550 ; p<0.001)$. Thus, the higher the depression score, the worse the physical function, role functioning and emotional functioning indices of participants (Table 3 ).

Moderate negative correlation was found between role functioning and anxiety $(r=-0.411 ; p<0.001)$, and emotional functioning and anxiety $(r=-0.699 ; p<0.001)$, indicating that the higher the anxiety score, the worse the role and emotional functioning (Table 3). 
Table 2 - Description of the means and standard deviation of the quality of life assessment instrument (QLQ-C30*), São Paulo, São Paulo, Brazil, 2015-2016

\begin{tabular}{lcc}
\hline Scales & Mean & Standard deviation \\
\hline General health status/QOL ${ }^{+}$ & 71.0 & 23.7 \\
Physical functioning & 71.4 & 25.2 \\
Paper performance & 75.7 & 31.0 \\
Emotional functioning & 68.1 & 26.0 \\
Cognitive functioning & 78.4 & 26.0 \\
Social functioning & 73.7 & 32.1 \\
Fatigue & 29.2 & 27.8 \\
Nausea and vomiting & 13.1 & 24.6 \\
Pain & 22.0 & 32.7 \\
Dyspnea & 7.8 & 18.1 \\
Insomnia & 30.5 & 37.2 \\
Loss of appetite & 25.6 & 37.6 \\
Constipation & 17.1 & 31.8 \\
Diarrhea & 12.8 & 24.5 \\
Financial difficulties & 35.5 & 41.8 \\
\hline Note:*EORT-QLQ-C30-Quality of Life Questionnaire Core-30, ${ }^{\dagger}$ QOL - quality of life.
\end{tabular}

Table 3 - Correlation between the quality of life (QLQ-C30*) and anxiety and depression (HADS) scales - São Paulo, São Paulo, Brazil, 2015-2016

\begin{tabular}{lcccc}
\hline & \multicolumn{2}{c}{ HADS $^{\dagger}$ Anxiety } & \multicolumn{2}{c}{ HADS Depression } \\
& $\mathbf{( r )}^{\dagger}$ & $\boldsymbol{p}$ value & $(\mathbf{r})$ & $\boldsymbol{p}$ value \\
\hline General health status/QOL & -0.477 & 0.000 & -0.504 & 0.000 \\
Physical functioning & -0.331 & 0.001 & -0.487 & 0.000 \\
Role functioning & -0.411 & 0.000 & -0.523 & 0.000 \\
Emotional functioning & -0.699 & 0.000 & -0.550 & 0.000 \\
Cognitive functioning & -0.328 & 0.001 & -0.372 & 0.000 \\
Social functioning & -0.284 & 0.003 & -0.349 & 0.000 \\
Fatigue & 0.408 & 0.000 & 0.488 & 0.000 \\
Nausea and vomiting & 0.123 & 0.208 & 0.372 & 0.000 \\
Pain & 0.298 & 0.002 & 0.351 & 0.000 \\
Dyspnea & 0.119 & 0.222 & 0.094 & 0.337 \\
Insomnia & 0.273 & 0.004 & 0.241 & 0.012 \\
Loss of appetite & 0.210 & 0.030 & 0.327 & 0.001 \\
Constipation & 0.216 & 0.025 & 0.327 & 0.001 \\
Diarrhea & 0.011 & 0.907 & 0.128 & 0.188 \\
Financial difficulties & 0.116 & 0.233 & 0.208 & 0.032
\end{tabular}

Note: ${ }^{*}$ EORTC-QLQ-C30 - Quality of Life Questionnaire Core- $30,{ }^{+} H A D S-H o s p i t a l$ Anxiety and Depression Scale, ${ }^{\ddagger}(r)$ - Pearson's Correlation Coefficient, ${ }^{5} Q V$ - Quality of Life.

Moreover, moderate positive correlation was observed between fatigue and anxiety $(r=0.408 ; p<0.001)$, and fatigue and depression $(r=0.488 ; p<0.001)$, suggesting that the higher the anxiety and depression scores, the worst is the fatigue intensity (Table 3 ).

Weak positive correlations were observed between physical symptoms (nausea, pain, insomnia, loss of appetite, constipation), depression and anxiety (Table 3 ).

\section{DISCUSSION}

The analysis of the sample's sociodemographic profile showed characteristics similar to other studies that evaluated cancer patients ${ }^{(30-31)}$, and observed a predominance of female patients, who live with a companion, and with 55 years as the mean age. These data confirm information from Inca, which points higher incidence of cancer in people over 40 years of age ${ }^{(1,32-33)}$.

Regarding the symptoms during cancer treatment, fatigue, insomnia, pain, loss of appetite, depression and anxiety presented high prevalence, similar to the findings of other studies that evaluated cancer patients s3-34). $^{(33}$.

Fatigue is one of the most common symptoms in cancer patients, especially for those who undergo chemotherapy or radiation therapy. The prevalence of fatigue was high in this study, a similar result to those found in studies conducted in other countries, with the same patient profile(35-36).

A study that analyzed fatigue in patients with colorectal cancer in the state of São Paulo found lower prevalence values than the ones found in this study, and showed that depression, functioning and sleep disorders were the strongest predictors of fatigue, i.e., in the presence of all these factors the probability of fatigue was $80 \%$, in the absence, however, it fell to $8 \%{ }^{(15)}$. These data corroborate the results found in this study since a moderate positive correlation between fatigue and depression was observed, i.e., patients with higher depression scores showed higher fatigue scores.

An investigation that linked the worsening of quality of life with the presence of fatigue and depression suggested that these symptoms, as comorbidities, may deepen the damages to the general health status of patients ${ }^{(37)}$.

The analyses of this study showed higher prevalence values of anxiety and depression than those found in the general population $^{(2,7,38)}$. Both symptoms showed negative correlation with the patients' emotional functioning and role functioning, indicating that symptoms of anxiety and depression are related to losses in these function scales, inevitably affecting the quality of life.

Studies show that anxiety and depression symptoms are more frequent in cancer patients than in those with other types of chronic diseases; thus, showing the importance of early detection of symptoms for the improvement of these conditions. A study published in 2017 assessed the incidence of anxiety and depression prior to chemotherapy, in addition to the impact of these symptoms on quality of life, and found anxiety in $21.8 \%$ of patients and depression in $23.6 \%$, showing moderate negative correlation between these symptoms and quality of life, further confirming the findings of this study ${ }^{(38)}$.

Given that cancer treatment can cause many changes in the patients' lives, which may collaborate for increased symptoms of depression and anxiety, as evidenced in this work, the multiprofessional team must be aware of these demonstrations to perform the necessary referrals.

Although pain was not the symptom with greater intensity in this study, it was frequent and showed positive correlation with symptoms of depression and anxiety, suggesting a relationship with them. Other studies have confirmed the association between the presence of pain in cancer, symptoms of anxiety and depression and impairments to quality of life $\mathrm{e}^{(39-40)}$. A study conducted in China showed that better quality of life was associated with lower intensity of pain, and less interference of this symptom in the disease process ${ }^{(40)}$, thus stressing the importance of effective control of pain in cancer patients.

The presence of symptoms can affect the physical, emotional and cognitive functioning, having influence on the quality of life. Emotional and physical functioning were the most affected in the study sample.

Similar mean general QOL values were found in a Brazilian study with patients undergoing chemotherapy ${ }^{(33)}$. On the other hand, investigations that evaluated women with cancer undergoing radiotherapy ${ }^{(41)}$ and chemotherapy ${ }^{(42-43)}$ found higher general QOL indices. 
A study on the quality of life of cancer patients on chemotherapy also used the EORTC QLQ-C30 scale and showed that more intense pain and high fatigue levels were significantly related to lower quality of life $(p<0.05)^{(44)}$. Another study assessed the association between quality of life with pain, anxiety and depression, and found strong negative correlation between quality of life and depression ( $r=-0.73)$, moderate negative correlation between quality of life and pain $(r$ $=-0.41)$ and between quality of life and anxiety $(r=-0.65)^{(45)}$. These data are similar to those of this study, which also found negative correlations between quality of life, depression and anxiety.

\section{Study limitations}

The use of convenience sampling can be considered a limitation since it makes the generalization of the findings more difficult, representing only the patients of the institution where the study was conducted. Moreover, one of the inclusion criteria was minimum 4 years of schooling, given the possible difficulty of understanding the measurement instruments. This decision, however, prevented the participation of illiterate patients or with minimal schooling, which can be considered a potential bias.

\section{Contributions to the fields of nursing and health}

This study brings important contributions to the field of nursing because it shows the most prevalent symptoms in cancer patients who are under treatment by chemotherapy and radiation therapy, in addition to analyzing the relationship of these symptoms with the quality of life. Having knowledge of the most frequent symptoms in this group of patients and the relationship with the quality of life enables nurses to better plan nursing care in chemotherapy and radiotherapy services, which can result in increased security and better quality of care.

\section{CONCLUSIONS}

Fatigue, insomnia, pain and loss of appetite were the more frequent and more intense symptoms among cancer patients undergoing chemotherapy or radiation therapy. Anxiety and depression symptoms presented a negative correlation with quality of life and functioning, and positive correlation with different physical symptoms.

Despite the many advances in cancer treatment, the prevalence of physical and emotional symptoms still is high and can affect the quality of life of these patients. More effective strategies must be adopted to manage the symptoms.

\section{FUNDING}

This study was financed by Sao Paulo Research Foundation (FAPESP), Process 2015/10308-8. This study was financed in part by the Coordenação de Aperfeiçoamento de Pessoal de Nível Superior - Brasil (CAPES) - Finance Code 001.

\section{ACKNOWLEDGMENT}

We thank ICESP for the support of the study and for Isadora Cardoso Salles, Juliana Rodrigues Martins, Fernanda Moreira Leite e Martha Letícia Aguirre Quintero by the important contribution in data collection.

\section{REFERENCES}

1. Instituto Nacional de Câncer (INCA). Estimativa 2018: incidência de câncer no Brasil [Internet]. Rio de Janeiro: INCA; 2018 [cited 2018 Mar 13]. Available from: http://www.inca.gov.br/estimativa/2018/estimativa-2018.pdf

2. Santichi EC, Benute GRG, Juhas TR, Peraro EC, Lucia MCS. Rastreio de sintomas de ansiedade e depressão em mulheres em diferentes etapas do tratamento para o câncer de mama. Psicol Hosp [Internet]. 2012 [cited 2017 Oct 10];10(1):42-67. Available from: http://pepsic.bvsalud. org/scielo.php?script=sci_arttext\&pid=S1677-74092012000100004

3. Stafford L, Judd F, Gibson P, Komiti A, Mann GB, Quinn M. Anxiety and depression symptoms in the 2 years following diagnosis of breast or gynaecologic cancer: prevalence, course and determinants of outcome. Support Care Cancer. 2015; 23(8):2215-24. doi: 10.1007/ s00520-014-2571-y

4. Simard S, Thewes B, Humphris G, Dixon M, Hayden C, Mireskandari S, et al. Fear of cancer recurrence in adult cancer survivors: A systematic review of quantitative studies. J Cancer Surviv. 2013;7(3):300-22. doi: 10.1007/s11764-013-0272-z

5. Addington HJ. The legacy of cancer on depression and anxiety. Lancet Oncol. 2013;14(8):675-6. doi: 10.1016/S1470-2045(13)70238-9

6. Ng CG, Mohamed S, See MH, Harun F, Dahlui M, Sulaiman AH, et al. Anxiety, depression, perceived social support and quality of life in Malaysian breast cancer patients: a 1-year prospective study. Health Qual Life Outcomes. 2015;13(1):205. doi: 10.1186/s12955-015-0401-7

7. Zigmond AS, Snaith RP. The hospital anxiety and depression scale. Acta Psychiatr Scand. 1983;67(6):361-70. doi: 10.1111/j.1600-0447.1983. tb09716.x

8. Ferreira AS, Bicalho BP, Oda JMM, Duarte SJH, Machado RM. Breast cancer: prevalence of anxiety and depression in outpatients. Arq Ciênc Saude UNIPAR. 2016;19(3):185-9. doi: 10.25110/arqsaude.v19i3.2015.5548

9. Paula JM, Sonobe HM, Nicolussi AC, Zago MMF, Sawada NO. Symptoms of depression in patients with cancer of the head and neck undergoing radiotherapy treatment: a prospective study. Rev Latino-Am Enfermagem. 2012;20(2):1-7. doi: 10.1590/ S0104-11692012000200020

10. Fisch MJ, Lee JW, Weiss M, Wagner LI, Chang VT, Cella D, et al. Prospective, observational study of pain and analgesic prescribing in medica oncology outpatients with breast, colorectal, lung, or prostate cancer. J Clin Oncol. 2012;30(16):1980-8. doi: 10.1200/JCO.2011.39.2381 
11. World Health Organization (WHO). WHO's pain relief ladder [Internet]. Geneva:WHO; 2016 [cited 2017 Sept 20]. Available from: http://www. who.int/cancer/palliative/painladder/en

12. Campos MPO, Hassan BJ, Riechelmann R, del Giglio A. Cancer-related fatigue: a review. Rev Assoc Med Bras. 2011;57(2):206-14. doi: 10.1590/ S0104-42302011000200021

13. Panobianco MS, Magalhães PAP, Soares CR, Sampaio BAL, Almeida AM, Gozzo TO, et al. Prevalência de depressão e fadiga em um grupo de mulheres com câncer de mama. Rev Elet Enf. 2012;14(3):532-40. doi: 10.5216/ree.v14i3.14409

14. Lamino DA, Pimenta CAA, Braga PE, Mota DDCF. Fadiga clinicamente relevante em mulheres com câncer de mama: prevalência e fatores associados. Invest Enferm. Imagen Desarr. 2015;17(1):65-76. doi: 10.11144/Javeriana.IE17-1.fcrm

15. Mota DDCF, Pimenta CAM, Caponero R. Fatigue in colorectal cancer patients: prevalence and associated factors. Rev Lat Am Enfermagem. 2012;20(3):495-503. doi: 10.1590/S0104-11692012000300010

16. Gozzo TO, Moysés AMB, Silva PR, Almeida AM. Nausea, vomiting and quality of life in women with breast cancer receiving chemotherapy. Rev Gaúcha Enferm. 2013;34(3):110-6. doi: 10.1590/S1983-14472013000300014

17. Brateibach V, Domenico ELB, Berlezi EM, Loro MM, Rosanelli CLSP, Gomes JS, et al. Sintomas de pacientes em tratamento oncológico. Rev Ciênc Saúde. 2013;6(2):102-9. doi: 10.15448/1983-652X.2013.2.12604

18. Roque VMN, Forones NM. Avaliação da qualidade de vida e toxicidades em pacientes com câncer colorretal tratados com quimioterapia adjuvante baseada em fluoropirimidinas. Arq Gastroenterol. 2006;43(2):94-101. doi: 10.1590/S0004-28032006000200007.

19. Costa AIS, Chaves MD. Pain in cancer patients under chemotherapy. Rev Dor. 2012;13(1):45-9. doi: 10.1590/S1806-00132012000100008

20. Parreiras FC, Wainstein AJ, Morete M, Géo LS. Prevalence of pain among melanoma patients. Rev Dor. 2016;17(1):39-42. doi: 10.5935/1806-0013.20160010

21. Brant JM, Eaton LH, Irwin MM. Cancer-related pain: assessment and management with putting evidence into practice interventions. Clin J Oncol Nurs. 2017;21(Suppl 3):4-7. doi: 10.1188/17.CJON.S3.4-7

22. Rafihi-Ferreira RE, Soares MRZ. Insônia em pacientes com câncer de mama. Estud Psicol. 2012;29(4):597-607. doi: 10.1590/ S0103-166X2012000400014

23. Rafihi-Ferreira RE, Pires MLN, Soares MRZ. Sono, qualidade de vida e depressão em mulheres no pós-tratamento de câncer de mama. Psicol Refl Crit. 2012;25(3):506-13. doi: 10.1590/S0102-79722012000300010

24. Schag CC, Heinrich RL, Ganz PA. Karnofsky performance status revisited: reliability, validity, and guidelines. J Clin Oncol. 1984;2(3):187-93. doi: 10.1200/JCO.1984.2.3.187

25. Schaafsma J, Osaba D. The Karnofsky Performance Scale re-examined: a cross validation with EORTC-C30. Qual Life Res. 1994;3(6):413-24. doi: 10.1007/BF00435393

26. Instituto Nacional de Câncer (INCA). Cuidados Paliativos Oncológicos - Controle de Sintomas. Rev Bras Cancerol [Internet]. 2002 [cited 2017 Oct 20];48(2):191-211. Available from: http://www1.inca.gov.br/rbc/n_48/v02/pdf/condutas3.pdf

27. Bergerot CD, Laros JA, Araujo TCCF. Avaliação de ansiedade e depressão em pacientes oncológicos: comparação psicométrica. Psico USF. 2014;19(2):187-97. doi: 10.1590/1413-82712014019002004

28. Marcolino JAM, Mathias LAST, Piccinini Filho L, Guaratini AA, Suzuki FM, Alli LAC. Hospital anxiety and depression scale: a study on the validation of the criteria and reliability on preoperative patients. Rev Bras Anestesiol. 2007;57(1):52-62. doi: 10.1590/ S0034-70942007000100006

29. Paiva CE, Carneseca EC, Barroso EM, Camargos MG, Alfano AC, Rugno FC, et al. Further evaluation of the EORTC QLQ-C30 psychometric properties in a large Brazilian cancer patient cohort as a function of their educational status. Support Care Cancer. 2014;22(8):2151-60. doi: $10.1007 / \mathrm{s} 00520-014-2206-3$

30. Andrade V, Sawada NO, Barichello E. Quality of life in hematologic oncology patients undergoing chemotherapy. Rev Esc Enferm USP. 2013;47(2):350-6. doi: 10.1590/S0080-62342013000200012

31. Kawakami DM, Olah SL, Pivetta NRS, Silva RCR, Santos DCN, Napoleão LL, et al. Evaluation of anxiety and depression in oncology patients who undergo ambulatory chemotherapy. Colloq Vitae. 2014;6(3):35-41. doi: 10.5747/cv.2014.v06.n3.v109

32. Menezes CCS, Ferreira DBB, Faro FBA, Bomfim MS, Trindade LMDF. Colorectal cancer in the Brazilian population: mortality rate in the 20052015 period. Rev Bras Promoç Saude. 2016;29(2):172-9. doi: 10.5020/18061230.2016.p172

33. Sawada NO, Nicolussi AC, Okino L, Cardozo FMC, Zago MMF. Quality of life evaluation in cancer patients to submitted to chemotherapy. Rev Esc Enferm USP. 2009;43(3):578-84. doi: 10.1590/S0080-62342009000300012

34. Nicolussi AC, Sawada NO. Quality of life of patients with colorectal cancer who were receiving complementary therapy. Acta Paul Enferm. 2009;22(2):155-61. doi: 10.1590/S0103-21002009000200007

35. Jean-Pierre P, Morrow GR, Roscoe JA, Heckler C, Mohile S, Janelsins M, et al. A phase III randomized, placebo-controlled, double-blind clinical trial of the effect of modafinil on cancer-related fatigue among 631 patients receiving chemotherapy: A University of Rochester Cancer Center Community Clinical Oncology Program research base study. Cancer. 2010;116(14):3513-20. doi: 10.1002/cncr.25083

36. Hofman M, Ryan JL, Figueroa-Moseley CD, Jean-Pierre P, Morrow GR. Cancer-related fatigue: the scale of the problem. Oncologist. 2007;12(Suppl 1):4-10. doi: 10.1634/theoncologist.12-S1-4 
37. Santos J, Mota DDCF, Pimenta CAM. Comorbidities between fatigue and depression in patients with colorectal câncer. Rev Esc Enferm USP. 2009;43(4):904-9. doi: 10.1590/S0080-62342009000400024

38. Simão DAS, Aguiar ANA, Souza RS, Captein KM, Manzo BF, Teixeira AL, et al. Qualidade de vida, sintomas depressivos e de ansiedade no início do tratamento quimioterápico no câncer: desafios para o cuidado. Enferm Foco. 2017;8(2):82-6. doi: 10.21675/2357-707X.2017. v8.n2.874.

39. Cardoso G, Graca J, Klut C, Trancas B, Papoila A. Depression and anxiety symptoms following cancer diagnosis: a cross-sectional study. Psychol Health Med. 2016;21(5):562-70. doi: 10.1080/13548506.2015.1125006

40. Barrett M, Chu A, Chen J, Lam KY, Portenoy R, Dhingra L, et al. Quality of life in community-dwelling chinese american patients with cancer pain. J Immigr Minor Health. 2017;19(6):1442-8. doi: 10.1007/s10903-016-0392-4

41. Silveira CF, Regino PA, Soares MBO, Mendes LC, Elias TC, Silva SR. Quality of life and radiation toxicity in patients with gynecological and breast cancer. Esc Anna Nery 2016;20(4):e20160089. doi: 10.5935/1414-8145.20160089

42. Lôbo SA, Fernandes AFC, Almeida PC, Carvalho CML, Sawada NO. Quality of life in women with breast cancer undergoing chemotherapy. Acta Paul Enferm. 2014;27(6):554-9. doi: 10.1590/1982-0194201400090

43. Nicolussi AC, Sawada NO, Cardozo FMC, Andrade V, Paula JM. Health-related quality of life of cancer patients undergoing chemotherapy. Rev Rene. 2014;15(1):132-40. doi: 10.15253/2175-6783.2014000100017

44. Heydarnejad MS, Hassanpour DA, Solati DK. Factors affecting quality of life in cancer patients undergoing chemotherapy. Afr Health Sci [Internet]. 2011 [cited 2017 Oct 20];11(2):266-70. Available from: https://www.ncbi.nlm.nih.gov/pmc/articles/PMC3158510/

45. Capela C, Marques AP, Assumpção A, Sauer JF, Cavalcante AB, Chalot SD, et al. Associação da qualidade de vida com dor, ansiedade e depressão. Fisioter Pesqui. 2009;16(3):263-8. doi: 10.1590/S1809-29502009000300013 